\title{
The Health and Safety Impact of Construction Project Features
}

Patrick Manu, Nii Ankrah, David Proverbs and Subashini Suresh

DOI: $10.1108 /$ ECAM-07-2012-0070

'This article is (c) Emerald Group Publishing and permission has been granted for this version to appear here (http:http://eprints.uwe.ac.uk/22144/). Emerald does not grant permission for this article to be further copied/distributed or hosted elsewhere without the express permission from Emerald Group Publishing Limited.' 


\begin{abstract}
Purpose - Despite the established significance of underlying accident causes to health and safety (H\&S), and the persistent reporting of the underlying accident causal influence of construction project features (CPFs) which emanate from pre-construction decisions, no empirical research has focussed on CPFs in terms of assessing their degree of potential to influence accident occurrence. This study therefore investigates this facet of the accident causal influence of CPFs.

Design/methodology/approach - A mixed method design was used involving semi-structured interviews, and a questionnaire survey of UK construction professionals.

Findings - CPFs generally have a moderate or a high potential to influence accident occurrence, implying a fair or severe potential to cause harm in terms of the H\&S of workers. The degree of potential of CPFs to influence accident occurrence is influenced by: the extent to which certain proximate causes of accidents are common/prevalent within CPFs; and the degree of potential of those proximate causes to influence accident occurrence.

Originality/value - These findings provide insight into the H\&S consequences of CPFs, awareness of which is essential if pre-construction project participants are to implement appropriate risk control measures especially in the early phases of projects to mitigate the accident causal influence of CPFs. The findings reinforce the contribution of clients and their design and project management teams to accident causation, the significance of the early planning of $\mathrm{H} \& \mathrm{~S}$ in construction project delivery, and the importance of driving mechanisms such as the Construction (Design and Management) Regulations 2007.
\end{abstract}

Keywords - accident, construction industry, health and safety, project features.

\title{
Introduction
}

Although UK health and safety $(H \& S)$ statistics indicate a trend of H\&S improvements in the construction industry, the industry still has an unenviable reputation of being one of the worst industries in the UK in respect of H\&S performance (cf. HSE, 2011a). Injuries and fatalities associated with construction accidents impose a huge cost on the industry (Pearce, 2003). For the over two million construction workforce (cf. ONS, 2011) and indeed the wider society all of whom are at risk, this is clearly unacceptable. H\&S has become an important objective on construction projects (cf. Office of Government Commerce, 2004) thanks to drivers such as legislation (e.g. the Construction (Design and Management) Regulations 2007 (CDM 2007) and the Health and Safety Offences Act 2008), efforts of the HSE in prosecuting offenders, and the growing realisation by organisations that their workforce are their most valuable resource (Fellows et al., 2002). Consequently, this has created the need to implement measures that will reduce the rate of accidents on construction sites. The identification of appropriate measures and the effectiveness of their application however rely on the in-depth understanding of factors influencing accidents on sites. To this end several construction accident causation studies have been undertaken some of which have reported two major hierarchies of accident causal factors namely: underlying/root accident factors and proximate factors (Suraji et al., 2001; Haslam et al., 2005). It has been highlighted that there is the need to pay attention to the underlying causal factors in order to have sustained improvement in H\&S (Haslam et al., 2005; Brace et al., 2009). This need is reinforced by the fact that the underlying accident factors emerge from the preconstruction stage of project procurement where project participants have an enormous ability to influence H\&S through their decisions and H\&S planning (Szymberski, 1997; Brabazon et al., 2000). Despite the importance of underlying causes of accident to H\&S, there has generally been very limited research on these causes (see Appendix 1). 
Construction project features (CPFs) being organisational, physical and operational attributes of construction projects, fall in this category of underlying causal factors as they emanate from preconstruction decisions by clients, designers and project managers/planners and contribute to accident causation. Despite the persistent reporting of the accident causal influence of CPFs such as nature of project, method of construction, project duration, level of construction, subcontracting, design complexity, site restriction and procurement system (as summarised by Table I), not much detailed empirical research has focused on understanding the extent of their causal influence.

\section{[Insert Table I]}

Even among the studies which have examined underlying causes of accidents in construction, no specific focus has been accorded to examining the accident causal phenomenon of CPFs (cf. Haslam et al., 2005; Cooke and Lingard, 2011; Behm and Schneller, 2012). This could be attributed to the inherent difficulties in examining underlying causes of accidents whose influence tends to be latent (cf. Haslam et al., 2005; Bomel Limited et al., 2006; Cooke and Lingard, 2011). This study therefore assesses the degree of potential of CPFs to influence accident occurrence (i.e. their potential to cause accident/harm in respect of the H\&S of worker). In the sections that follow, a review of the accident causal influence of CPFs is presented leading to the posing of hypotheses relating to the degree of potential of CPFs to influence accident occurrence. The methodological approach for testing the hypotheses is then presented together with the arguments in support of the approach. The findings emerging from the data analysis are subsequently presented and discussed followed by the implications of the findings and concluding remarks.

\section{The degree of potential of CPFs to influence accident occurrence}

Manu et al. (2010) through an extensive review of H\&S literature within the construction industry built a robust case to show that CPFs are inherently associated with certain site-based accident causal factors. Based on the systems view of accident causation (e.g. the ConstraintResponse model (Suraji et al., 2001) and the ConCA model (Haslam et al., 2005)) these factors can be considered as being proximate accident factors which are inherently introduced by CPFs to give rise to accidents. From the review by Manu et al. (2010), it is seen that CPFs have varying degrees of potential to influence accident occurrence. The review also suggests that this is due to a varying extent to which the proximate accident factors associated with CPFs are common/prevalent within CPFs. This implies that the more common/prevalent a proximate factor is within a $\mathrm{CPF}$, the greater the degree of potential of the $\mathrm{CPF}$ to influence accident occurrence. This understanding has informed the development of a conceptual assessment of the degree of potential of CPFs to influence accident occurrence as given in Table II. From Table II, for instance, a complex design has greater potential to influence accident occurrence than a simple design due to the greater extent to which difficulty in constructing (i.e. buildability) is common within a complex design than within simple design.

Whilst the comparative assessment in Table II derives from the extant literature, there is no further indication in this literature as to the specific degree of potential of CPFs to influence accident occurrence. Arguably, it is more insightful knowing the specific measure/degree of harmfulness of a CPF than just knowing that one CPF is more harmful than the other, and this is because the CPF which is less harmful could still pose great danger despite it comparatively 
having less harmfulness. Conversely the CPF with the comparatively greater harmfulness may even not pose any danger as its actual measure of harmfulness may not be dire. Apart from this limitation, the assessment provided by literature (as summarised by Table II) is only confined to CPFs of the same kind (e.g. comparing pre-assembly construction to traditional method of construction) with no mechanism for comparing across different categories (e.g. comparing preassembly to low-level construction). These limitations constitute a gap in H\&S literature which requires addressing. Despite these limitations, the insight from Table II can be instrumental in facilitating further empirical studies to augment current understanding of the degree of potential of CPFs to influence accident occurrence, particularly the view that the degree of potential of a $\mathrm{CPF}$ to influence accident occurrence is influenced by the extent to which its proximate factor(s) is common/prevalent within it. Taking the conceptualisation a step further, it is argued in Manu et al. $(2010 ; 2012)$ that the degree of potential of a CPF to influence accident occurrence is also influenced by the degree of potential of its proximate factor(s) to influence accident occurrence. This is based on the logic that it is by reason of the proximate factor influencing accident occurrence (i.e. having the potential to cause accidents) that the CPF also influences accident occurrence as a result of its inherent introduction of that proximate factor. This can be likened to the argument by Duffus and Worth (2001) in support of the influence of exposure on risk (Chicken and Posner, 1998; Duffus and Worth, 2001) that, regardless of the degree of a hazard if there is no exposure there will be no risk. Synthesising all these arguments, it can generally be conceptualised that the degree of potential of a CPF to influence accident occurrence (represented by ' $C$ ') is a combined effect of:

- the extent to which its proximate factor(s) is prevalent/common within the CPF (represented by ' $r$ '); and

- the degree of potential of its proximate factor(s) to influence accident occurrence (represented by ' $\mathbf{R}$ ').

\section{[Insert Table II]}

Unlike the degree of prevalence of proximate factor (i.e. ' $r$ ') which allows for relative comparison among CPFs of the same kind in terms of their degree of potential to influence accident occurrence (as shown in Table II), the combined effect of ' $\boldsymbol{r}$ ' and ' $\boldsymbol{R}$ ' could allow for relative comparison across all CPFs as the combined effect would take into account the direness (in other words the harmfulness) of the proximate factors. This conceptualisation coherently unifies the above arguments and provides the way forward for the empirical verification of the espoused relationships between ' $C$ ', ' $r$ ', and ' $R$ '. To advance the verification of these relationships two hypotheses can be put forward for testing.

Based on the suggestion in the literature that greater degree of potential of a CPF to influence accident occurrence is due to greater prevalence of proximate factor within a CPF (as summarised by Table I), it is thus expected that:

H1: The degree to which a proximate factor(s) is common/prevalent within a CPF will be significantly and positively related to the degree of potential of the CPF to influence accident occurrence.

In line with the argument that if a proximate factor has no potential to influence accident occurrence, its associated $\mathrm{CPF}$ will have no potential to influence accident occurrence regardless of the degree of prevalence of the proximate factor, it is also expected that: 
H2: The relationship between the degree to which a proximate factor(s) is common/prevalent within a CPF and the degree of potential of the CPF to influence accident occurrence will be moderated by the degree of potential of the proximate factor(s) to influence accident occurrence such that the relationship becomes more positive as the degree of potential of the proximate factor(s) to influence accident occurrence becomes more positive.

\section{Research methodology}

A mainly quantitative approach was adopted as this kind of inquiry is well noted for its appropriateness for testing prior formulations (Fellows and Liu, 2008; Creswell, 2009). Construction accident causation studies have often involved analysis of accident records (cf. Arboleda and Abraham, 2004; Behm, 2005; Hinze et al., 2005; Ling et al., 2009). However, in the case of this study, the acknowledgement by several researchers that investigating underlying/root causes of accidents (which are upstream of project procurement) using accident records poses difficulties (cf. Suraji et al., 2001; Bomel Limited et al., 2006; Cooke and Lingard, 2011) meant that using accident records was not considered ideal in this study. In order therefore to get reliable data for diagnosing the degree of potential of CPFs to influence accidents, contractor personnel were deemed a potential source of data given that they often witness and/or experience accidents on site. Contractor personnel such as project managers, construction managers, H\&S managers, and site managers, commonly work on project sites in management roles and also from their wide industrial experience in construction are likely to be aware of the CPFs being investigated as well as any impact they have on H\&S. These professionals were thus targeted in a questionnaire survey to elicit their views on the accident causal influence of CPFs. The use of questionnaires is not uncommon in construction H\&S studies (cf. Langford et al., 2000; Kheni et al., 2008; Frontline Consultants, 2011) and in particular construction accident causation studies (cf. Whittington et al., 1992; Hide, 2003). To aid the development of the questionnaire, an initial phase of semi-structured interviews was conducted. The preliminary use of interviews in this study is similar to the sequential application of interviews and a survey by Langford et al. (2000) in their H\&S study. Creswell (2009) hails the utility of such mixed method approach for the development of an instrument to be administrated in a survey.

\section{Phase 1: Interview}

11 experienced construction professionals comprising H\&S managers, project managers, site managers, a construction manager and a construction H\&S consultant were interviewed. Averagely the practitioners have 26 years of experience in construction. The interviews explored the practitioners' experiences and perspectives of the accident causal influence of CPFs thus providing the opportunity to draw out important aspects of this causal phenomenon such as the proximate factors associated with CPFs. The interviews were audio taped and on the average took 60 minutes. The interviews were transcribed verbatim and the transcripts were systematically analysed through iterative re-reading and colour coding of the transcripts using a qualitative codebook derived from the literature (Creswell, 2009).

The analysis confirmed that nature of project, method of construction, site restriction, project duration, procurement system, design complexity, level of construction, and subcontracting have accident implications as has been previously reported in literature (summarised in Table I). Commenting on some of these features, one interviewee for instance emphasized that, "A complex project brings more risk, a restricted site brings more risk, a tight duration brings more risk and a high rise also brings more risk but you've got to manage those risks by putting in place the right measures to mitigate those risks." 
In addition to the above project features, another feature which emerged as having accident implications is restriction of site locality as revealed by the narrative below.

\section{"It was a refurbishment and we were putting a new roof on the podium roof and it was right in the centre of Nottingham City Centre...Inner city jobs are usually more dangerous with H\&S because they are very tight" [Project Manager].}

The project features were considered as being underlying accident causal factors with one interviewee (a H\&S manager) even referring to them as, "...something that sits behind everything...they are underlying and quite deep underlying root causes". The analysis further revealed that the project features are associated with certain site-based H\&S issues which as a result make the project features influence the occurrence of accidents. With regards to restriction of site locality this was associated with difficulty in traffic (pedestrian and vehicle) control around site vicinity. Regarding nature of project, method of construction, site restriction, project duration, procurement system, design complexity, level of construction, and subcontracting, there was congruence between the associated H\&S issues drawn from the interviews and the proximate factors identified in the literature (given in Table II). The interviews thus provided preliminary confirmation of the prior formulations and in conjunction with the literature constituted the basis for the development of the questionnaire for the survey phase.

\section{Phase 2: Questionnaire Survey}

From the hypotheses, the questionnaire was designed to measure three variables:

1. the degree of potential of CPFs to influence accident occurrence;

2. the degree of potential of proximate factors to influence accident occurrence; and

3. degree to which proximate factors are common within CPFs.

The variables were measured using a Likert-type 5-point scale similar to that used in a previous accident causation study (cf. Hide, 2003). The questionnaire captured the judgment of practitioners regarding the above three variables using close-ended questions/statements (e.g. rate the potential of the listed project features to influence accident occurrence). An open-ended question was also included to solicit general comments on the accident causal influence of CPFs. To be able to gauge the expertise and experience of the practitioners which is important to the credibility of their judgement and hence the research findings, the questionnaire also requested relevant background information relating to the practitioners' expertise and experience in construction (cf. Hallowell and Gambatese, 2009). Contractor personnel, especially those in construction management roles (e.g. H\&S manager, project manager, construction manager and site manager), were the target source of data. As there is no organised record/database for these professionals, it was considered that a viable means of reaching them would be through their employers' contacts (i.e. contractors). The survey was thus conducted on a sample of contractors randomly drawn from the UK Kompass online directory. A total of 1000 questionnaires were administered electronically (i.e. 420 questionnaires) and by post (i.e. 580 questionnaires) to contractors requesting participation of a professional in construction management role. The survey yielded 187 responses giving a response rate of $18.7 \%$. Following a missing data pattern analysis, 3 responses were excluded for excessive missing data ( $>50 \%)$ (cf. Hair et al., 2010). The effective sample size for the analysis was therefore 184 responses (i.e. effective response rate of $18.4 \%$ ). It is reported in Takim et al. (2004) that the response rate norm for questionnaire survey is $20-30 \%$. Although the effective response rate obtained in this survey is slightly lower than the norm suggested by Takim et al. (2004), this should be weighed against the difficulty in obtaining participation in H\&S studies in the UK due to the legalities surrounding H\&S in the UK (cf. Gibb et al., 2002). Even lower response rates have been recorded in other UK based 
construction management surveys (e.g. $12.2 \%$ response rate recorded by Li et al. (2005) and $5.14 \%$ effective response rate recorded by Sutrisna et al., 2005)).

Analysis: The ratings by the respondents were aggregated by mean calculation. In order for the mean ratings to be interpreted with any confidence, evidence of significant agreement among the raters/respondents is essential hence the estimation of inter-rater agreement using James et al. (1984) single item inter-rater agreement index $\left(\mathrm{r}_{\mathrm{WG}}\right)$. Following the recommendation by Cohen $e t$ al. $(2001,2009)$ the $r_{W G}$ values for significant agreement were estimated by running simulations based on a uniform null distribution using a sample size (i.e. group size) of 184 and a number of response items of 5 (i.e. the 5-point scale). To test the hypotheses, regression analysis (ordinary least square) was undertaken given its appropriateness for investigating the existence and nature of relationships between variables (Hair et al., 2010). In testing hypothesis H1, degree of potential of CPFs to influence accident occurrence (i.e. the outcome variable) and degree of prevalence of proximate factors within CPFs (i.e. the predictor variable) were applied in the regression. To test hypothesis $\mathrm{H} 2$, degree of potential of CPFs to influence accident occurrence (i.e. the outcome variable), degree of prevalence of proximate factors within CPFs (i.e. the predictor variable), degree of potential of proximate factors to influence accident occurrence (i.e. the moderator variable) and the product of the predictor and moderator variables (i.e. the moderator effect/interaction term- $R \times \boldsymbol{r}$ ) were applied in step-wise multiple regression, with the test of moderation being the significance of the interaction term (Baron and Kenny, 1986; Hair et al., 2010). SPSS v 16 and the R Software were used to aid the analysis. The analysis of the general comments was undertaken inductively using emerging codes (cf. Creswell, 2009).

\section{Results}

\section{Demographic information}

The respondents' roles were: H\&S manager (56.52\%), construction manager (15.76\%), project manager $(7.61 \%)$, site manager $(2.17 \%)$, and other construction management roles $(17.94 \%)$. Averagely, the respondents have 16.30 years of experience $($ Std. Dev. $=10.45)$ and 24.31 years of experience $($ Std. Dev. $=11.97)$ in their current role and in construction respectively. A banded breakdown of the experience of the respondents (i.e. $<5$ years, 5-10 years, 11-15 years, 16-20 years, and over 20 years) indicates that approximately $90 \%$ of the respondents have at least 5 years of experience in their role and approximately 80\% have over 10 years of experience in construction. Approximately $70 \%$ of the respondents are members of at least one industrial professional body. The professional bodies include: Institution of Occupational Health and Safety, International Institution of Risk and Safety Management, Institution of Civil Engineers, Chartered Institute of Building, The Institution of Royal Engineers, Institution of EngineersIreland, Association of Professional Safety and the Royal Institute of Chartered Surveyors. In terms of highest educational attainment, approximately $50 \%$ of the respondents have a Diploma or higher (i.e. Bachelors, Masters Degree or PhD) in a construction related discipline. From the respondents' demographic information, it is evident that the experience and expertise of the respondents is respectable and they are well placed to adequately respond to the subject being studied. Their responses can thus be regarded as important and reliable, and findings drawn from their responses a sound and credible representation of the accident causal influence of CPFs.

\section{The degree of potential of CPFs to influence accident occurrence}

Table III indicates a summary of the assessment of the degree of potential of the CPFs to influence accident occurrence. The $r_{W G}$ indices indicate significant consensus amongst the respondents with regards to their assessment. This means that the aggregated (i.e. mean) ratings 
can be considered as being a "good" representation of the respondents' professional judgement of the degree of potential of the CPFs to influence accident occurrence. When the mean ratings are rounded to the nearest point on the assessment scale to ensure conformity with the scale so as to aid interpretation, the eventual overall assessment shows that the CPFs are generally considered as having a high or moderate potential to influence accident occurrence, implying that CPFs generally have a severe or fair potential to cause harm in terms of the H\&S of workers.

\section{[Insert Table III]}

\section{Hypotheses testing}

Descriptive statistics and $\mathrm{r}_{\mathrm{WG}}$ indices calculated for the respondents' rating of the degree of potential of the proximate factors to influence accident occurrence and also the degree to which the proximate factors are common/prevalent within CPFs are given in Tables IV and V. The tables also show overall assessments by approximation of the mean ratings to the nearest scale point to aid their interpretation in conformity with the 5-point scales. From this approximation, it is seen that generally the proximate factors have a high or moderate potential to influence accident occurrence (see Table IV), and the degree of prevalence of proximate factors within the CPFs is low, moderate or high (see Table V). More importantly, the $r_{\mathrm{WG}}$ indices are evidence of significant consensus amongst the respondents and were therefore an indication that the regression analysis using the mean ratings would yield trustworthy results. The output of the regression analysis for hypothesis $H 1$ is given in Table VI. It shows that prevalence of proximate factor within $\mathrm{CPF}$ is significantly and positively related to degree of potential of CPF to influence accident occurrence $(\beta=0.77, \mathrm{p}<0.001)$. Prevalence of proximate factor within $\mathrm{CPF}$ accounts for $85 \%$ of the variance in potential of CPF to influence accident occurrence. In all, the results thus support hypothesis $H 1$ as being true. The output of the regression analysis for hypothesis $H 2$ is given in Table VII. From the step-wise regression only the interaction term was selected for inclusion in the model. The value of $\mathrm{R}^{2}$ for the model generated is .859 , implying that the interaction term accounts for $85 \%$ of the variation in potential of CPF to influence accident occurrence. The $\beta$-value of the interaction term being significant $(\beta=0.241, \mathrm{p}<0.001)$ gives evidence of moderation (Baron and Kenny, 1986; Hair et al., 2010). Also the $\beta$-value being positive indicates a positive relationship as hypothesised. The results therefore support hypothesis $\mathrm{H} 2$ as being true.

For the two regression models, four diagnostic checks were run: linearity of the phenomenon measured, constant variance of the error terms, independence of the error terms, and normality of the error term (Field, 2005; Hair et al., 2010). Linearity of phenomenon and constant variance of error terms were checked by scatter plots of the standardized residuals against the predicted values, and normality of error term was checked by histogram plots and normal probability plots (Field, 2005; Hair et al., 2010). These plots showed no signs of violation of their respective assumptions. To test for the independence of the error terms, the Durbin-Watson test was used. The Durbin-Watson statistics obtained (as given in Tables VI and VII) are between 1 and 3 indicating that this assumption was also not violated (Field, 2005).

[Insert Table IV]

[Insert Table V] 
[Insert Table VI]

[Insert Table VII]

Comments on the accident causal influence of CPFs

A third of the participants provided brief comments which mainly reflected some of the views expressed in the interview phase. Two CPFs were frequently mentioned as being a major concern within the industry. These are tight project schedules and designs with features which impinge on buildability. Respondents were of the view that quite often little consideration is given by clients and their design and project management teams as to the H\&S impact of these features despite relevant requirements under the CDM 2007. In connection to this, CDM Coordinators were portrayed as not being of much influence in advising clients and their design and project management teams on these matters. Some extracts indicating these concerns are:

"In my experience the two greatest factors that influence accidents on site are time constraintsprogramme, and design buildability.” [H\&S Manager]

"The CDM Regs. stipulates that time is a resource. It is my experience that CDM-Coordinators do not challenge project timescales, and contractors due to scarcity of work are willing to take on the challenge and increased risk factors. " [H\&S Manager]

“Many projects have short timescales.” [Health, Safety, Environmental and Quality Manager]

\section{Discussion}

The generic assessment of the potential of CPFs to influence accident occurrence (given in Table III) reveals both expected and unexpected results. The overall assessment of a moderate or a high potential to influence accident occurrence, confirms that CPFs have varying degrees of potential to influence accident occurrence. The overall assessments of: demolition and refurbishment (high) relative to new work (moderate); high level construction and underground construction (high) relative to low level construction (moderate); tight project duration (high) relative to adequate project duration (moderate); multi-layer subcontracting (high) relative to single-layer subcontracting (moderate); complex design (high) relative to simple design (moderate); restricted site (high) relative to unrestricted site (moderate); and restricted site locality (high) relative to unrestricted site locality (moderate), converge with the comparative assessments in the literature (given in Table II) and also reflect comments from the interviews such as:

“...A complex project brings more risk, a restricted site brings more risk, a tight duration brings more risk and a high rise also brings more risk..." [Project Manager]

Surprisingly, the procurement methods all generally have moderate potential to influence accident occurrence despite reports in literature which suggest that design and build and partnering improve $\mathrm{H} \& \mathrm{~S}$ as they allow for collaborative working among project team members and hence foster better H\&S management (cf. Matthews and Rowlinson, 1999; Brabazon et al., 2000; Hide et al., 2003). This also contradicts views from the interview phase such as the quote below which support the notion that collaborative procurement methods offer better health and safety outcomes.

“...without doubt, design and build is the safest way to build than tradition contract." [Senior Site Manager] 
Another surprising assessment from Table III is that despite the reported H\&S benefits of preassembly construction (cf. Wright et al., 2003; McKay, 2010), it is generally judged as having the same moderate potential to influence accident occurrence as traditional method of construction. This also contradicts views from the interview phase such as the quote below which express that pre-assembly is better than traditional method of construction in terms of achieving good H\&S outcomes.

"The more that can be done off-site the less the risk. I've done modular student accommodation where
everything comes fitted out in a complete box and you stack one box on top of another. It's a very
quick operation and very safe." [Project Manager]

The results from the hypotheses testing provide evidence that the degree of potential of a CPF to influence accident occurrence (denoted by ' $C$ ') is influenced by: the extent to which its proximate factor(s) is prevalent/common within the CPF (denoted by ' $\boldsymbol{r}$ '); and the degree of potential of its proximate factor(s) to influence accident occurrence (denoted by ' $\boldsymbol{R}$ '). This is supported by the substantial variance (i.e. 85\%) that prevalence of proximate factor and the interaction term (i.e. $r \times R$ ) accounted for in potential of CPF to influence accident occurrence. The results imply that, greater prevalence of a proximate factor within a CPF (i.e. $\boldsymbol{r}$ ) coupled with greater potential of the proximate factor to influence accident occurrence (i.e. $\boldsymbol{R}$ ) yields greater potential of the CPF to influence accident occurrence (i.e. $C$ ). However, a lesser ' $r$ ' coupled with a greater ' $\boldsymbol{R}$ ', and conversely, a lesser ' $\boldsymbol{R}$ ' coupled with a greater ' $\boldsymbol{r}$ ', yields a lesser ' $C$ '. Also a lesser ' $\boldsymbol{r}$ ' coupled with a lesser ' $\boldsymbol{R}$ ', yields a lesser ' $\boldsymbol{C}$ '.

The findings of the hypotheses testing provide some scope for explaining the surprising generic assessments relating to procurement methods and methods of construction. From the overall assessment, it was found that the procurement methods generally have similar potential to influence accident occurrence (i.e. moderate). From Table V, it can also be seen that the degree of prevalence of fragmentation of project team within the procurement methods is also generally assessed as being similar (i.e. moderate) and this conforms with the suggestion that the real cultural change from adversarial relationships to collaborative relationships heralded by approaches like partnering is not being fully embraced (Bresnen and Marshall, 2000; Sullivan, 2006). A comments from the survey which also reflects this view is that: "Partnering and collaborative working has collapsed. This is having a significant effect on site H\&S performance." In view of the supported hypothesis H1 it is thus only consequential that the procurement methods generally have a similar potential to influence accident occurrence as the degree of prevalence of fragmentation of project team within them is also generally similar. Therefore, a plausible reason for the procurement systems having similar potential to influence accident occurrence is that there is also a similar degree of fragmentation of project team within the procurement systems.

Also concerning the surprising generic assessment regarding traditional construction and preassembly, in view of the supported hypothesis $H 2$, one plausible explanation is that it is due to manual handling and mechanical handling generally having similar degree of potential to influence accident occurrence (i.e. moderate) as shown from the overall assessment in Table IV. Given industry-wide mechanisms to address manual handling such as The Manual Handling Operations Regulations 1992 (amended in 2002) and supporting revised industry guidance such as "Getting to Grips with Manual Handling" (INDG143(rev2) (HSE, 2011b), it is possible that safer manual handling techniques are increasingly being practiced and hence manual handling being generally assessed as having a moderate potential to influence accident occurrence. Again, from Table V it can be seen that the extent to which mechanical handling is common/prevalent 
within traditional construction and pre-assembly is generally similar (i.e. moderate). Therefore, in view of the supported Hypothesis $H 1$, another plausible explanation for the surprising finding is that it is due to similar extent of mechanical handling within both methods of construction, which perhaps is the result of increasing construction technologies requiring more mechanical means of handling for in-situ construction.

From the general comments, it appears there is concern from some members of the industry (i.e. contractors) that more still needs doing in addressing the H\&S impact of CPFs especially during the pre-construction stages. The recurring view that unrealistic project schedules and intricate designs are commonplace raises concern, especially when there are regulations such as the CDM 2007 which place legal obligation on clients to allow sufficient time for all the stages of a project, and also impose legal obligation on designers to take into account the buildability of design.

Overall, despite the emergence of both expected and unexpected findings, a new perspective provided by the study is the specific measure/degree of potential to influence accident occurrence (i.e. moderate or high) resulting from CPFs, and in addition, the insight into the factors which influence this potential. The overall assessment given by this study thus allows for comparison across all CPFs which represents a step forward in understanding the H\&S impacts of CPFs. These insights have implications for pre-construction H\&S planning and these are considered in the subsequent section.

\section{Implications of findings for pre-construction H\&S planning}

Seeing that pre-construction H\&S planning has a significant influence on the H\&S outcomes of projects (Szymberski, 1997; Brabazon et al., 2000) and given that CPFs emanate from preconstruction decisions, the insights given by this study could be useful to pre-construction decision-makers (i.e. client, designers and project planners/managers) in terms of informing decisions which determine CPFs. CPFs which have moderate potential to influence accident occurrence could thus be chosen over those with a high potential to influence accident occurrence. The findings on the degree of potential of CPFs to influence accident occurrence could also provide the necessary stimulus for the industry as a whole to place greater emphasis on addressing CPFs which have a high potential to influence accident occurrence while giving due attention to CPFs which have moderate potential to influence accident occurrence. To this end, the findings could thus inform the allocation of resources and efforts towards devising accident prevention strategies. For example, tight project timescale which has been shown to have a high potential to influence accident occurrence and has been suggested to be commonplace within the industry despite relevant legal requirements should attract the attention of industry stakeholders.

The insight into the factors which influence the degree of potential of CPFs to influence accident occurrence could also be useful to pre-construction decision makers as well as the construction team in providing evidence-based justification for devising and implementing effective risk control measures to mitigate the potential of CPFs to influence accident occurrence. Such risk control measures could be targeted at mitigating the prevalence of proximate factors within CPFs and/or mitigating the potential of proximate factors to influence accident occurrence (i.e. their potential to cause harm). In practical terms, mitigating the potential of proximate factors to cause harm would mean implementing measures which makes proximate factors safer or measures 
which would make it safe for workers to operate within conditions imposed by proximate factors.

In a broader perspective, the findings reinforce the contribution made by pre-construction project participants to the causation of accidents and thereby also reinforce the importance of mechanisms such as the CDM 2007 which places H\&S legal obligations on these project participants in the design, planning and management of projects from the early stage.

\section{Conclusions}

Against the background of limited studies on underlying causes of accidents, this study has been undertaken in an effort to close the gap in knowledge regarding the degree of potential of CPFs to influence accident occurrence. Through the application of a mixed method design, this study has provided an assessment of the degree of potential of CPFs to influence accident occurrence which goes beyond the simple comparative assessments among CPFs of the same kind. The assessment given by this study indicates that CPFs generally have a moderate or a high potential to influence accident occurrence meaning they have a fair or severe potential to cause harm in terms of the H\&S of workers (and in some cases members of public). It is clearly evident that the accident causal influence of CPFs cannot be underestimated or ignored. From the results of the hypotheses testing, the study has also provided empirical evidence that the degree of potential of a CPF to influence accident occurrence is influenced by: the extent to which its proximate factor(s) is common/prevalent within the CPF; and the degree of potential of the proximate factor(s) to influence accident occurrence. These findings have implications for pre-construction H\&S planning in terms of making decisions which determine CPFs and also in terms of devising/implementing appropriate risk control measures. The findings reinforce the contribution of clients and their design and project management teams to accident causation and hence the significance of the early planning of $\mathrm{H} \& \mathrm{~S}$ in construction project delivery and the importance of driving mechanisms such the CDM 2007. Considering that the opportune period to influence safety on projects is the pre-construction stage, the insight provided by this research presents an early opportunity for pre-construction project participants, and indeed construction phase participants, to positively influence $H \& S$ on projects by effectively managing the accident causal influence of CPFs through pre-construction H\&S planning and decision-making which determines CPFs.

\section{Limitations and future work}

The study has limitations which need highlighting. Construction accident causation is a complex and multi-faceted phenomenon. Mitigating the accident causal influence of CPFs alone will therefore not automatically yield accident-free projects. Nonetheless, this is important as part of efforts to prevent accidents on construction sites. The complexity of accident causation could manifest through inter-causal relationships among accident factors which could mitigate or aggravate the potential of accident factors to influence accident occurrence. However, in terms of the degree of potential of CPFs to influence accident occurrence, the assessment given by this study are generic independent assessments which do not take into account the effects of potential inter-causal relationships from other causes of accidents. Although an attempt to measure some form of a resultant degree of potential of CPFs to influence accident occurrence which quantifies the effects of all possible inter-causal relationships will be a herculean task (if not impracticable, due to the dynamism of construction activity which would mean dynamic degree of potential of CPFs to influence accident occurrence) it would be worth knowing what potential inter-causal relationships exist. Such knowledge could complement the assessments given in this study in 
terms of, for example informing the selection or avoidance of certain combinations of CPFs. To this end, it is worth proposing further studies into the accident causal influence of CPFs to explore inter-causal relationships which could transpire in the process of accident causation by CPFs.

\section{References}

Abdelhamid and Everett (2000), "Identifying root causes of construction accidents", Journal of Construction Engineering and Management, Vol. 126 No. 1, pp.52-60.

Ankrah, N.A. (2007), "An investigation into the impact of culture on construction project performance", PhD Thesis, University of Wolverhampton, Wolverhampton.

Anumba, C., Egbu, C. and Kashyap, M. (2006), Avoiding structural collapses in refurbishment A decision support system, HSE Books, Suffolk.

Anumba, C., Marino, B., Gottfried, A. and Egbu, C. (2004), Health and safety in refurbishment involving demolition and structural instability, HSE Books, Suffolk.

Arboleda, C.A. and Abraham, D.M. (2004), "Fatalities in trenching operations-Analysis using models of accident causation", Journal of Construction Engineering and Management, Vol. 130 No. 2, pp.273-280.

Aulin, R. and Ågren, R. (2012), "Occupational accidents profile of the construction industry in Sweden", in Tjandra, I.K. (ed) Proceeding of CIB W099 Conference, September 2012, Singapore.

Baiden, B., Price, A. and Dainty, A. (2006), "The extent of team integration within construction projects", International Journal of Project Management, Vol. 24 No. 1, pp.13-23.

Baron, R.M. and Kenny, D.A. (1986), "The moderator-mediator variable distinction in social psychological research: Conceptual, strategic, and statistical considerations", Journal of Personality and Social Psychology, Vol. 51 No. 6, pp.1173-1182.

Behm, M. (2005), "Linking construction fatalities to the design for construction safety concept", Safety Science, Vol 43 No. 8, pp.589-611.

Behm, M. and Schneller, A. (2012), "Application of the Loughborough construction accident causation model: a framework for organizational learning" Construction Management and Economics, doi:10.1080/01446193.2012.690884, pp. 1-16.

Bomel Limited, Glasgow Caledonian University and The Institute for Employment Research (2006), An analysis of the significant causes of fatal and major injuries in construction in Scotland- Factors influencing Scottish construction accidents-FISCA, HSE Books, Suffolk.

Brabazon, P., Tipping, A. and Jones, J. (2000), Construction health and safety for the new Millennium, HSE Books, Suffolk.

Brace, C., Gibb, A., Pendlebury, M. and Bust, P. (2009), Phase 2 Report:Health and safety in the construction industry: Underlying causes of construction fatal accidents -External research, Her Majesty's Stationery Office, Norwich.

Bresnen, M. and Marshall, N. (2000), "Partnering in construction: a critical review of issues, problems and dilemmas", Construction Management and Economics, Vol. 18 No. 2, pp.229-237.

Chi, C.F., Chang, T.C. and Ting, H.I. (2005), "Accident patterns and prevention measures for fatal occupational falls in the construction industry", Applied Ergonomics, Vol. 36 No. 4, pp.391-400.

Chicken, J.C. and Posner, T. (1998), The philosophy of risk, Thomas Telford, London.

Choudhry, R.M. and Fang, D. (2008), "Why operatives engage in unsafe work behavior: Investigating factors on construction sites", Safety Science, Vol. 46 No. 4, pp.566-584. 
Chua, D.K.H. and Goh, Y.M. (2005), "Poisson model of construction incident occurrence", Journal of Construction Engineering and Management, Vol. 131 No.6, pp.715-722.

Cohen, A., Doveh, E. and Eick, U. (2001), "Statistical properties of the rwg(j) index of agreement", Psychological Methods, Vol. 6 No. 3, pp.297-310.

Cohen, A., Doveh, E. and Nahum-Shani, I. (2009), "Testing agreement for multi-item scales with the indices rwg(j) and ADm(j)", Organizational Research Methods, Vol. 12 No. 1, pp.148-164.

Cooke, T. and Lingard, H. (2011), "A retrospective analysis of work-related deaths in the Australian construction industry", in Egbu, C. and Lou, E. C. W. (eds.) Proceedings of 27th Annual ARCOM Conference, 5-7 September 2011, Bristol, Association of Researchers in Construction Management, pp.279-288.

Creswell, J.W. (2009), Research design: qualitative, quantitative, and mixed method approaches, 3rd ed., Sage Publications, California.

Dewlaney, K.S. and Hallowell, M. (2012), "Prevention through design and construction safety management strategies for high performance sustainable building construction", Construction Management and Economics, Vol. 30 No. 2, pp. 165-177.

Duffus, J. and Worth, H. (2001), The science of chemical safety essential toxicology- An educational resource, International Union of Pure and Applied chemistry.

Egawa, Y. and Nakamura, T. (2000), Analysis and experimental study on labor accidents related to communication in construction work, Research Institute for Industrial Safety.

Egbu, C.O. (1999), "Skills, knowledge and competencies for managing construction refurbishment works", Construction Management and Economics, Vol. 17 No. 1, pp.29-43.

Eriksson, P.E. (2010), "Partnering: what is it, when should it be used, and how should it be implemented?", Construction Management and Economics, Vol. 28 No. 9, pp.905-917.

Fellows, R., Langford, D., Newcombe, R. and Urry, S. (2002), Construction management in practice, Wiley-Blackwell, Oxford.

Fellows, R. and Liu, A. (2008), Research methods for construction, Blackwell Pubishing, West Sussex.

Field, A. (2005), Discovering statistics using SPSS, 2nd ed., Sage Publications Ltd, London.

Frontline Consultants (2011), Evaluation of Construction (Design and Management) Regulations 2007- Pilot study, HSE Books, Suffolk.

Gherardi, S., Nicolini, D. and Odella, F. (1998), "What do you mean by safety? Conflicting perspectives on accident causation and safety management in a construction firm", Journal of Contingencies and Crisis Management, Vol. 6 No. 4, pp.202-213.

Gibb, A.G.F. (1999), Priciples in off-site frabrication, Whittles, Caithness.

Gibb, A.G.F. (2001), "Standardization and pre-assembly-distinguishing myth from reality using case study research", Construction Management and Economics, Vol. 19 No. 3, pp.307315.

Gibb, A.G., Haslam, R.A., Gyi, D.E., Hide, S., Hastings, S. and Duff, R. (2002), "ConCAPreliminary results from a study of accident causality", in Rowlinson, S. (ed.) Proceeding of Triennial Conference CIB W099, May 2002, University of Hong Kong, Hong Kong.

Greenwood, D and Wu, S. (2012), "Establishing the association between collaborative working and construction project performance based on client and contractor perceptions", Construction Management and Economics, Vol. 30 No. 4, pp. 299-308.

Hair, J.F., Black, W.C., Babin, B.J., Anderson, R.E. and Tatham, R.L. (2010), Multivariate data analysis with readings, 7 ed., Pearson/Prentice Hall, Upper Saddle River.

Hallowell, M.R. and Gambatese, J.A. (2009), "Construction safety risk mitigation", Journal of Construction Engineering and Management, Vol. 135 No. 12, pp.1316 -1323. 
Hamid, A., Rahim, A., Majid, A., Zaimi, M. and Singh, B. (2008), "Causes of accidents at construction sites", Malaysian Journal of Civil Engineering, Vol. 20 No. 2, pp.242-259.

Haslam, R.A., Hide, S.A., Gibb, A.G.F., Gyi, D.E., Pavitt, T., Atkinson, S. and Duff, A.R. (2005), "Contributing factors in construction accidents", Applied Ergonomics, Vol. 36 No. 4, pp.401-415.

Hide, S. (2003), Exploring accident causation in the construction industry, PhD Thesis, Loughborough University, Loughborough.

Hide, S., Atkinson, S., Pavitt, T., Haslam, R., Gibb, A., Gyi, D, Duff, R. and Suraji, A. (2003), Causal factors in construction accidents, HSE Books, Suffolk.

Hinze, J. (1996), “The distraction theory of accident causation”, in Alvez Diaz, L. M. and Coble, R. J. (eds.) Proceeding of International conference on implementation of safety and health on construction sites, CIB Working Commission W099: Safety and health on Construction, 4-7 September, Lisbon, Portugal.

Hinze, J., Huang, X. and Terry, L. (2005), "The nature of struck-by accidents", Journal of Construction Engineering and Management, Vol. 131 No. 2, pp.262-268.

Hinze, J., Pedersen, C. and Fredley, J. (1998), "Identifying root causes of construction injuries", Journal of Construction Engineering and Management, Vol. 124 No. 1, pp.67-71.

Horbury, C. and Hope, C. (1999), The impact of procurement and contracting practices on health and safety - A review of literature, HSL, Buxton.

HSE (2009), Construction intelligence report: Analysis of construction injury and ill-health intelligence, HSE.

HSE (2011a), Construction work related injuries and ill health, HSE.

HSE (2011b), Getting to grips with manual handling: A short guide. INDG143(rev2), HSE Books, Suffolk.

Hughes, P. and Ferrett, E. (2008), Introduction to health and safety in construction, 3rd ed., Elsevier Ltd, Oxford.

James, L.R., Demaree, R.G. and Wolf, G. (1984), "Estimating within-group interrater reliability with and without response bias", Journal of Applied psychology, Vol. 69 No. 1, pp.85-98.

Kartam, N.A. and Bouz, R.G. (1998), "Fatalities and injuries in the Kuwaiti construction industry. Accident Analysis and Prevention", Vol. 30 No. 6, pp.805-814.

Kheni, N.A., Dainty, A.R.J. and Gibb, A. (2008), "Health and safety management in developing countries: a study of construction SMEs in Ghana", Construction Management and Economics, Vol. 26 No. 11, pp.1159-1169.

Lam, S.W. and Rowlinson, S. (1997), "Causes of accidents in the construction industry in Hong Kong", Safety and Health Practitioner, Vol. 15 No. 7.

Langford, D., Rowlinson, S. and Sawacha, E. (2000), "Safety behaviour and safety management: its influence on the attitudes of workers in the UK construction industry", Engineering Construction and Architectural Management, Vol. 7 No. 2, pp.133-140.

Li, B., Akintoye, A., Edwards, P. and Hardcastle, C. (2005), "Perceptions of positive and negative factors influencing the attractiveness of PPP/PFI procurement for construction projects in the UK: Findings from a questionnaire survey", Engineering, Construction and Architectural Management, Vol. 12 No. 2, pp. 125-148.

Ling, F.Y.Y., Liu, M. and Woo, Y.C. (2009), "Construction fatalities in Singapore". International Journal of Project Management, Vol. 27 No. 7, pp.717-726.

Lubega, H., Kiggundu, B.M. and Tindiwensi, D. (2000), "An investigation into the causes of accidents in the construction industry in Uganda", in Proceeding of CSIR Building \& Construction Technology, 2nd International Conference on Construction in Developing Countries, November, Botswana. 
Manu, P., Ankrah, N., Proverbs, D. and Suresh, S. (2010), "An approach for determining the extent of contribution of construction project features to accident causation", Safety Science, Vol. 48 No. 6, pp.687-692.

Manu, P., Ankrah, N., Proverbs, D. and Suresh, S. (2011), "Managing the adverse health and safety impact of subcontracting: findings of a qualitative inquiry", in Laryea, S., Leiringer, R. and Hughes, W. (eds.) Proceedings of West Africa Built Environment Research (WABER) Conference, 19-21 July 2011, Accra, West Africa Built Environment Research (WABER) Conference.

Manu, P., Ankrah, N., Proverbs, D. and Suresh, S. (2012), "Investigating the multi-causal and complex nature of the accident causal influence of construction project features", Accident Analysis and Prevention, Vol. 48, pp. $126-133$.

Matthews, J. and Rowlinson, S. (1999), "Partnering: incorporating safety management", Engineering, Construction and Architectural Management, Vol. 6 No. 4, pp.347-357.

Mayhew, C. and Quinlan, M. (1997), "Subcontracting and occupational health and safety in the residential building industry", Industrial Relations Journal, Vol. 28 No. 3, pp.192-205.

McKay, L.J. (2010), The effect of offsite construction on occupational health and safety, $\mathrm{PhD}$ Thesis, Loughborough University, Loughborough.

McKay, L.J., Gibb, A.G.F., Haslam, R. and Pendlebury, M. (2002), "Implications for the effect of standardization and pre-assembly on health, safety and accident causality- preliminary results", in Greenwood, D. (ed.) Proceedings of 18th Annual ARCOM Conference, 2-4 September 2002, Association of Researchers in Construction Management.

McVittie, D., Banikin, H. and Brocklebank, W. (1997), "The effect of firm size on injury frequency in construction", Safety Science, Vol. 27 No. 1, pp.19-23.

Office of Government Commerce (2004), Achieving excellence in construction procurement guide 10: Health and Safety, Office of Government Commerce, London.

OSHA (1990), Analysis of construction fatalities, US Department of Labour, OSHA, Washington, D.C.

ONS (2011), Construction statistic annual 2011, ONS, Newport.

Pearce, D. (2003), The social and economic value of construction: The construction industry's contribution to sustainable development, nCRISP, London.

Perttula, P., Merjama, J., Kiurula, M. and Laitinen, H. (2003), "Accidents in materials handling at construction sites", Construction Management and Economics, Vol. 21 No. 7, pp.729736.

Strategic Forum for Construction (2002), Accelerating change- A report by the Strategic Forum for Construction, Chaired by Sir John Egan, Rethinking Construction, London.

Sullivan, M. (2006), “An open relationship", Construction Journal, June, pp.9-10.

Suraji, A., Duff, A.R. and Peckitt, S.J. (2001), "Development of a causal model of construction accident causation", Journal of Construction Engineering and Management, Vol. 127 No. 4, pp.337-344.

Sutrisna, M., Buckley, K., Potts, K. F., Proverbs, David G (2005) "A decision support tool for the valuation of variations on civil engineering projects", RICS Research Paper Series, Vol. 5 No. 7, pp. 1-41.

Szymberski, R.T. (1997), “Construction project safety planning”. TAPPI Journal, Vol. 80 No. 11, pp.69-74.

Takim, R., Akintoye, A. and Kelly, J. (2004), "Analysis of performance measurement in the Malaysian construction industry". in Ogunlana, S. O., Chareonngam, C., Herabet, P. and Hadikusumo, B. H. W. (eds.) Proceeding of Globalization and Construction, AIT Conference Centre, Bangkok, Thailand. 
Toole, T.M. (2002), “Construction site safety roles", Journal of Construction Engineering and Management, Vol. 128 No. 3, pp.203-210.

Whittington, C., Livingston, A. and Lucas, D.A. (1992), Research into management organizational and human factors in the construction industry, HSE Books, Suffolk.

Wright, M., Bendig, M., Pavitt, T. and Gibb, A. (2003), The case for CDM: better safer design-a pilot study, HSE Books, Suffolk.

[Insert Appendix 1] 
Table I. Literature sources highlighting the accident causal influence of CPFs

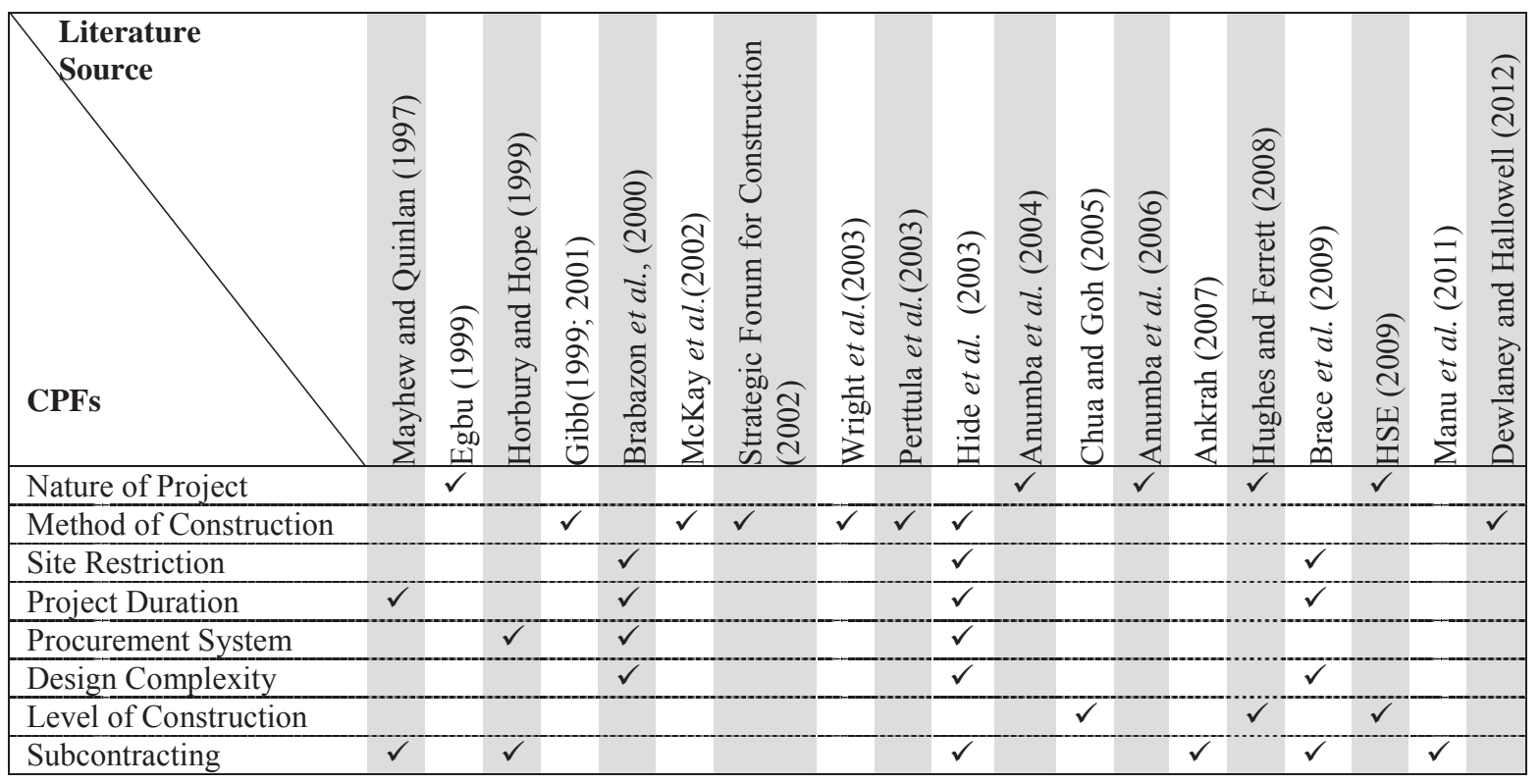


Table II. Potential of CPFs to influence accident occurrence

\begin{tabular}{|c|c|c|}
\hline \multirow[t]{2}{*}{ Proximate Factors } & \multicolumn{2}{|c|}{$\begin{array}{l}\text { Degree of Potential of CPFs to influence accident occurrence } \\
\text { (Degree of Prevalence of proximate factor within CPF) }\end{array}$} \\
\hline & Less & Greater \\
\hline $\begin{array}{l}\text { Uncertainty hazards (Egbu, } \\
\text { 1999; Anumba et al., 2006) }\end{array}$ & New work & $\begin{array}{l}\text { Refurbishment } \\
\text { Demolition }\end{array}$ \\
\hline $\begin{array}{l}\text { Manual handling, Mechanical } \\
\text { handling \& Housekeeping } \\
\text { problems (McKay et al., 2002; } \\
\text { Wright et al., 2003) }\end{array}$ & Pre-assembly construction & Conventional on-site construction \\
\hline $\begin{array}{l}\text { Site congestion (Hide et al., } \\
\text { 2003; Brace et al., 2009) }\end{array}$ & Unrestricted site & Restricted site \\
\hline $\begin{array}{l}\text { Time pressure (Hide et al., 2003; } \\
\text { Brace et al., 2009) }\end{array}$ & Unconstrained duration & Constrained duration \\
\hline $\begin{array}{l}\text { Fragmentation of project team } \\
\text { (Horbury and Hope, 1999; } \\
\text { Matthews and Rowlinson, 1999; } \\
\text { Brabazon et al., 2000; Hide et } \\
\text { al., 2003; Baiden et al., 2006; } \\
\text { Eriksson, 2010; Greenwood and } \\
\text { Wu, 2012) }\end{array}$ & Traditional procurement & Management contracting \\
\hline $\begin{array}{l}\text { Difficulty in constructing (Hide } \\
\text { et al., 2003; Brace et al., 2009) }\end{array}$ & $\begin{array}{c}\text { Simple Design } \\
\text { (Simple aesthetic qualities) }\end{array}$ & $\begin{array}{c}\text { Complex Design } \\
\text { (Intricate aesthetic qualities) }\end{array}$ \\
\hline $\begin{array}{l}\text { Working at height / Confined } \\
\text { space (Hughes and Ferrett, 2008; } \\
\text { HSE, 2009) }\end{array}$ & Low-level construction & $\begin{array}{l}\text { High-level construction } \\
\text { Underground construction }\end{array}$ \\
\hline $\begin{array}{l}\text { Fragmentation of work force } \\
\text { (Mayhew and Quinlan, 1997; } \\
\text { Hide et al., 2003; Ankrah, 2007) }\end{array}$ & Single-layer subcontracting & Multi-layer subcontracting \\
\hline
\end{tabular}


Table III. Assessment of degree of potential of CPFs to influence accident occurrence

\begin{tabular}{|c|c|c|c|c|c|}
\hline \multirow{2}{*}{ Construction Project Feature } & \multirow{2}{*}{ Mean } & \multirow{2}{*}{ Std. Dev. } & \multirow{2}{*}{${ }^{*} \mathbf{r}_{W G}$} & \multicolumn{2}{|c|}{ Overall Assessment } \\
\hline & & & & High (3) & Moderate (2) \\
\hline Demolition & 3.1739 & .95367 & 0.55 & $\checkmark$ & \\
\hline Underground construction & 2.8368 & .89677 & 0.60 & $\checkmark$ & \\
\hline Tight project duration & 2.8361 & .70531 & 0.75 & $\checkmark$ & \\
\hline High-level construction & 2.7554 & .89319 & 0.60 & $\checkmark$ & \\
\hline Multi-layer subcontracting & 2.6998 & .78400 & 0.69 & $\checkmark$ & \\
\hline $\begin{array}{l}\text { Complex design (i.e. design with intricate aesthetic } \\
\text { qualities) }\end{array}$ & 2.6141 & .84802 & 0.64 & $\checkmark$ & \\
\hline Restricted site & 2.6089 & .80872 & 0.67 & $\checkmark$ & \\
\hline Restricted site locality e.g. city centre location & 2.5703 & .76306 & 0.71 & $\checkmark$ & \\
\hline Refurbishment & 2.5169 & .92349 & 0.57 & $\checkmark$ & \\
\hline Traditional on-site construction & 2.2174 & .65830 & 0.78 & & $\checkmark$ \\
\hline New work & 1.9858 & .75112 & 0.72 & & $\checkmark$ \\
\hline Management contracting & 1.9499 & .76143 & 0.71 & & $\checkmark$ \\
\hline Design and build procurement & 1.8260 & .77698 & 0.70 & & $\checkmark$ \\
\hline Traditional method of procurement & 1.8058 & .81008 & 0.67 & & $\checkmark$ \\
\hline Unrestricted site locality e.g. outer city location & 1.7955 & .74548 & 0.72 & & $\checkmark$ \\
\hline Unrestricted site & 1.7949 & .78860 & 0.69 & & $\checkmark$ \\
\hline Partnering procurement & 1.7709 & .76016 & 0.71 & & $\checkmark$ \\
\hline Low-level construction & 1.7111 & .73799 & 0.73 & & $\checkmark$ \\
\hline Adequate project duration & 1.6558 & .72922 & 0.60 & & $\checkmark$ \\
\hline Single-layer subcontracting & 1.6252 & .72704 & 0.74 & & $\checkmark$ \\
\hline Simple design & 1.5475 & .73703 & 0.73 & & $\checkmark$ \\
\hline Pre-assembly construction & 1.5146 & .77634 & 0.70 & & $\checkmark$ \\
\hline
\end{tabular}

Notes: ${ }^{*} \mathrm{r}_{\mathrm{WG}}$ indices are based on a uniform null distribution. Based on 10,000 simulation runs, $\mathrm{r}_{\mathrm{WG}}$ values of $0.08,0.10$ and 0.14 are the $90 \%, 95 \%$ \& $99 \%$ confidence interval estimates respectively for group size of 184 and 5 response options. 
Table IV. Results of degree of potential of proximate factors to influence accident occurrence

\begin{tabular}{|c|c|c|c|c|c|}
\hline \multirow{2}{*}{ Proximate Factors } & \multirow{2}{*}{ Mean } & \multirow{2}{*}{ Std. Dev. } & \multirow{2}{*}{${ }^{*} \mathbf{r}_{W G}$} & \multicolumn{2}{|c|}{ Overall Assessment } \\
\hline & & & & High (3) & Moderate (2) \\
\hline Uncertainty of hazards & 3.1141 & .79823 & 0.68 & $\checkmark$ & \\
\hline Working at height & 2.9076 & .78032 & 0.70 & $\checkmark$ & \\
\hline Site congestion & 2.8913 & .66868 & 0.78 & $\checkmark$ & \\
\hline Time-pressure & 2.8750 & .71718 & 0.74 & $\checkmark$ & \\
\hline $\begin{array}{l}\text { Difficulty in traffic (i.e. vehicle and pedestrian) control } \\
\text { around site vicinity }\end{array}$ & 2.8261 & .74817 & 0.72 & $\checkmark$ & \\
\hline Working in confined space & 2.6881 & .88476 & 0.61 & $\checkmark$ & \\
\hline Difficulty in constructing (i.e. buildability) & 2.6522 & .76729 & 0.71 & $\checkmark$ & \\
\hline Housekeeping problems & 2.5888 & .73299 & 0.73 & $\checkmark$ & \\
\hline Fragmentation of workforce & 2.4825 & .74001 & 0.73 & & $\checkmark$ \\
\hline Fragmentation of project team & 2.4022 & .74745 & 0.72 & & $\checkmark$ \\
\hline Manual handling & 2.2306 & .75532 & 0.71 & & $\checkmark$ \\
\hline Mechanical handling & 1.9565 & .77408 & 0.70 & & $\checkmark$ \\
\hline
\end{tabular}


Table V. Results for extent to which proximate factor is common/prevalent within CPF

\begin{tabular}{|c|c|c|c|c|c|c|}
\hline \multirow[b]{2}{*}{$\begin{array}{l}\text { Extent to which proximate factor is } \\
\text { common/prevalent within CPF }\end{array}$} & \multirow[b]{2}{*}{ Mean } & \multirow[b]{2}{*}{ Std. Dev. } & \multirow[b]{2}{*}{$*^{*} \mathbf{r}_{W G}$} & \multicolumn{3}{|c|}{ Overall Assessment } \\
\hline & & & & $\begin{array}{l}\text { High } \\
(3)\end{array}$ & $\begin{array}{c}\text { Moderate } \\
\text { (2) }\end{array}$ & $\begin{array}{r}\text { Low } \\
(1)\end{array}$ \\
\hline Uncertainty of hazards within Refurbishment & 2.7714 & .93629 & 0.56 & $\checkmark$ & & \\
\hline Uncertainty of hazards within Demolition & 2.9324 & .94803 & 0.55 & $\checkmark$ & & \\
\hline Uncertainty of hazards within New work & 1.6246 & .73580 & 0.73 & & $\checkmark$ & \\
\hline Working at height within High-level construction & 3.1832 & .85076 & 0.64 & $\checkmark$ & & \\
\hline Working at height within Low-level construction & 1.9756 & .89674 & 0.60 & & $\checkmark$ & \\
\hline $\begin{array}{l}\text { Fragmentation of workforce within Single-layer } \\
\text { subcontracting }\end{array}$ & 1.7728 & .72886 & 0.73 & & $\checkmark$ & \\
\hline $\begin{array}{l}\text { Fragmentation of workforce within Multi-layer } \\
\text { subcontracting }\end{array}$ & 2.7273 & .80241 & 0.68 & $\checkmark$ & & \\
\hline $\begin{array}{l}\text { Fragmentation of project team within Traditional } \\
\text { procurement }\end{array}$ & 1.8553 & .74317 & 0.72 & & $\checkmark$ & \\
\hline $\begin{array}{l}\text { Fragmentation of project team within Design and Build } \\
\text { procurement }\end{array}$ & 1.8109 & .73153 & 0.73 & & $\checkmark$ & \\
\hline $\begin{array}{l}\text { Fragmentation of project team within Partnering } \\
\text { procurement }\end{array}$ & 1.8198 & .77830 & 0.70 & & $\checkmark$ & \\
\hline $\begin{array}{l}\text { Fragmentation of project team within Management } \\
\text { contracting }\end{array}$ & 2.0225 & .70703 & 0.75 & & $\checkmark$ & \\
\hline Manual handling within Pre-assembly construction & 1.7465 & .77017 & 0.70 & & $\checkmark$ & \\
\hline Manual handling within Traditional construction & 2.6614 & .69753 & 0.76 & $\checkmark$ & & \\
\hline Mechanical handling within Pre-assembly construction & 2.4021 & .91827 & 0.58 & & $\checkmark$ & \\
\hline Mechanical handling within Traditional construction & 2.3238 & .72411 & 0.74 & & $\checkmark$ & \\
\hline $\begin{array}{l}\text { Housekeeping problems within Pre-assembly } \\
\text { construction }\end{array}$ & 1.6178 & .80288 & 0.68 & & $\checkmark$ & \\
\hline Housekeeping problems within Traditional construction & 2.6827 & .72318 & 0.74 & $\checkmark$ & & \\
\hline Time-pressure within Tight project duration & 3.1322 & .67841 & 0.77 & $\checkmark$ & & \\
\hline Time-pressure within Adequate project duration & 1.7843 & .71232 & 0.75 & & $\checkmark$ & \\
\hline $\begin{array}{l}\text { Working in confined space within Underground } \\
\text { construction }\end{array}$ & 2.9240 & .87436 & 0.62 & $\checkmark$ & & \\
\hline Site congestion within Restricted site & 3.0472 & .71876 & 0.74 & $\checkmark$ & & \\
\hline Site congestion within Unrestricted site & 1.5992 & .68854 & 0.76 & & $\checkmark$ & \\
\hline Difficulty in constructing within Complex design & 2.8957 & .76707 & 0.70 & $\checkmark$ & & \\
\hline Difficulty in constructing within Simple design & 1.4367 & .65512 & 0.79 & & & $\checkmark$ \\
\hline $\begin{array}{l}\text { Difficulty in traffic control around site vicinity within } \\
\text { Restricted site locality }\end{array}$ & 3.0732 & .69869 & 0.76 & $\checkmark$ & & \\
\hline $\begin{array}{l}\text { Difficulty in traffic control around site vicinity within } \\
\text { Unrestricted site locality }\end{array}$ & 1.6104 & .75104 & 0.72 & & $\checkmark$ & \\
\hline
\end{tabular}

Notes: ${ }^{*} \mathrm{r}_{\mathrm{WG}}$ indices are based on a uniform null distribution. Based on 10,000 simulation runs, $\mathrm{r}_{\mathrm{WG}}$ values of $0.08,0.10$ and 0.14 are the $90 \%, 95 \%$ \& $99 \%$ confidence interval estimates respectively for group size of 184 and 5 response options. 
Table VI. Regression analysis for hypothesis H1

\begin{tabular}{|c|c|c|c|c|c|c|c|}
\hline $\mathrm{R}$ & .924 & $\mathrm{R}^{2}$ & .854 & Adjusted $\mathrm{R}^{2}$ & .847 & & \\
\hline Std. Error & .2011 & $\mathrm{R}^{2}$ Change & .854 & Durbin-Watson & 1.264 & & \\
\hline Analysis of & df & Sum of Squares & Mean Square & $\mathrm{F}$ & Sig. & & \\
\hline Regression & 1 & 4.740 & 4.740 & 117.122 & .000 & & \\
\hline Residual & 20 & .809 & .040 & & & & \\
\hline Total & 21 & 5.549 & & & & & \\
\hline Variables in & B & Std. Error & Beta & $\mathrm{t}$ & Sig. & Tolerance & VIF \\
\hline (Constant) & .402 & .169 & & 2.374 & .028 & & \\
\hline $\begin{array}{l}\text { Prevalence of } \\
\text { proximal factor(s) } \\
\text { within CPF }\end{array}$ & .773 & .071 & .924 & 10.822 & .000 & 1.000 & 1.000 \\
\hline
\end{tabular}


Table VII. Regression analysis for hypothesis H2

\begin{tabular}{|c|c|c|c|c|c|c|c|}
\hline $\mathrm{R}$ & .927 & $\mathrm{R}^{2}$ & .859 & Adjusted $\mathrm{R}^{2}$ & .852 & & \\
\hline Std. Error & .19785 & $\mathrm{R}^{2}$ Change & .859 & Durbin-Watson & 1.201 & & \\
\hline Analysis of & df & Sum of Squares & Mean Square & $\mathrm{F}$ & Sig. & & \\
\hline Regression & 1 & 4.766 & 4.766 & 121.759 & .000 & & \\
\hline Residual & 20 & .783 & .039 & & & & \\
\hline Total & 21 & 5.549 & & & & & \\
\hline $\begin{array}{l}\text { Variables in } \\
\text { equation }\end{array}$ & $\mathrm{B}$ & Std. Error & Beta & $\mathrm{t}$ & Sig. & Tolerance & VIF \\
\hline (Constant) & .671 & .143 & & 4.700 & .000 & & \\
\hline $\begin{array}{l}\text { Interaction term } \\
\text { (i.e. } \mathrm{R} \times \mathrm{r} \text { ) }\end{array}$ & .241 & .022 & .927 & 11.034 & .000 & 1.000 & 1.000 \\
\hline
\end{tabular}




\section{Appendix 1. Construction accident causation studies}

\begin{tabular}{|c|c|c|c|c|}
\hline Author & $\begin{array}{l}\text { Location } \\
\text { of study }\end{array}$ & Method of study & Causes of accident /findings & $\begin{array}{l}\text { Category of } \\
\text { causal factors }\end{array}$ \\
\hline $\begin{array}{l}\text { Occupational } \\
\text { Safety and } \\
\text { Health } \\
\text { Administration } \\
\text { (OSHA) (1990) }\end{array}$ & USA & $\begin{array}{l}\text { Analysis of } \\
\text { construction } \\
\text { fatalities. }\end{array}$ & $\begin{array}{l}33 \% \text { of the investigated fatalities are due } \\
\text { to falls, } 22 \% \text { are as a result of the victim } \\
\text { being struck-by an object, } 18 \% \text { are caught- } \\
\text { in between accidents, } 17 \% \text { are due to } \\
\text { electrocutions, and } 10 \% \text { are caused by } \\
\text { other conditions (e.g. toxic gases, } \\
\text { drowning, and fire). }\end{array}$ & $\begin{array}{l}\text { Proximate causes } \\
\text { which do not } \\
\text { extend upstream of } \\
\text { project } \\
\text { procurement. }\end{array}$ \\
\hline $\begin{array}{l}\text { Whittington et } \\
\text { al., (1992) }\end{array}$ & UK & $\begin{array}{l}\text { Analysis of } 30 \\
\text { accidents, } \\
\text { interviews, and } \\
\text { survey }\end{array}$ & $\begin{array}{l}\text { Three accident factors: headquarter issues } \\
\text { (e.g. problems with selection of } \\
\text { subcontractors or workforce, and } \\
\text { inadequate safety training of site } \\
\text { management or supervisors); site } \\
\text { management issues (e.g. failure to set up } \\
\text { safe work, and failure to communicate safe } \\
\text { system of work); and factors relating to the } \\
\text { injured person or his immediate work } \\
\text { colleagues (e.g. unsafe act/risk taking } \\
\text { behaviour, and miscommunications } \\
\text { between operatives on site). }\end{array}$ & $\begin{array}{l}\text { Proximate causes } \\
\text { which do not } \\
\text { extend upstream of } \\
\text { project } \\
\text { procurement. }\end{array}$ \\
\hline Hinze (1996) & USA & Desk study. & $\begin{array}{l}\text { Proposed that accidents are caused by } \\
\text { worker distraction either due to physical } \\
\text { hazards or mental diversion. }\end{array}$ & $\begin{array}{l}\text { Proximate causes } \\
\text { which do not } \\
\text { extend upstream of } \\
\text { project } \\
\text { procurement. }\end{array}$ \\
\hline
\end{tabular}

\begin{tabular}{lll}
\hline McVittie et al. $\quad$ Canada & Assessment of \\
& the influence of \\
& firm size on lost- \\
& time injury rates \\
& by reviewing \\
& records relating \\
& to injuries, man \\
& hours, payroll \\
& and firm size.
\end{tabular}

It was found that injury frequency increased consistently as firm size decreased. Factors responsible for this effect were suggested to include better organisation, greater awareness of health and safety, higher rates of unionisation and better training among larger firms.
Proximate causes which do not extend upstream of project procurement.

\begin{tabular}{ll}
\hline Lam and & Hon \\
Rowlinson & Kon
\end{tabular}

(1997)

Analysis of
government statistics.

Causes of accident are: difficulties in
adaptation for new immigrant workers,
employment of unskilled workers,
overtime work, lack of leadership from top
management, poor working attitudes,
shortage of factory inspectors, low
penalties for breaches of the safety law,
inadequate safety education courses,
inadequate authority of the Labour
Department, and poor site supervision.

Proximate causes
as well as
underlying causes
which extend
upstream of
project
procurement.

$34 \%$ of the investigated fatalities are due to falls, $18 \%$ are as a result of the victim being struck-by an object, $15 \%$ are caughtin between accidents, $20 \%$ are due to electrocutions, and $13 \%$ are caused by other conditions (e.g. toxic gases, drowning, and fire).

\begin{tabular}{lll}
\hline $\begin{array}{l}\text { Hinze } \text { et al. } \\
\text { (1998) }\end{array}$ & USA & $\begin{array}{l}\text { Analysis of 1,082 } \\
\text { accidents. }\end{array}$ \\
& & \\
\hline $\begin{array}{l}\text { Kartam and } \\
\text { Bouz (1998) }\end{array}$ & Kuwait & $\begin{array}{l}\text { Examined 148 } \\
\text { accidents. }\end{array}$ \\
\hline
\end{tabular}

Proximate causes which do not extend upstream of project procurement.
The causes of the accidents in the sample are: worker turnover and false acts; inadequate safety procedures; improper

\begin{tabular}{lll} 
inadequate safety procedures; improper & $\begin{array}{l}\text { Proximate causes } \\
\text { which do not } \\
\text { extend upstream of }\end{array}$ \\
\hline
\end{tabular}




\section{Appendix 1. Construction accident causation studies}

\begin{tabular}{lllll}
\hline Author & $\begin{array}{c}\text { Location } \\
\text { of study }\end{array}$ & Method of study & \multicolumn{1}{c}{ Causes of accident /findings } & $\begin{array}{c}\text { Category of } \\
\text { causal factors }\end{array}$ \\
\hline & & & $\begin{array}{l}\text { cleaning and unusable materials; and } \\
\text { destiny. }\end{array}$ & $\begin{array}{l}\text { project } \\
\text { procurement. }\end{array}$ \\
\hline $\begin{array}{llll}\text { Gherardi } \text { et al. } \\
(1998)\end{array}$ & Italy & $\begin{array}{l}\text { Interviewing of } \\
\text { construction site } \\
\text { engineers and site } \\
\text { managers. }\end{array}$ & $\begin{array}{l}\text { From the engineers' perspective, an } \\
\text { underlying cause of accident is human } \\
\text { error whereas the site managers consider } \\
\text { underlying causes of accidents to be } \\
\text { difficulties in site coordination, lack of } \\
\text { respect for safety norms, and lack of }\end{array}$ & $\begin{array}{l}\text { Proximate causes } \\
\text { project } \\
\text { procurement. }\end{array}$
\end{tabular}

organisational control.

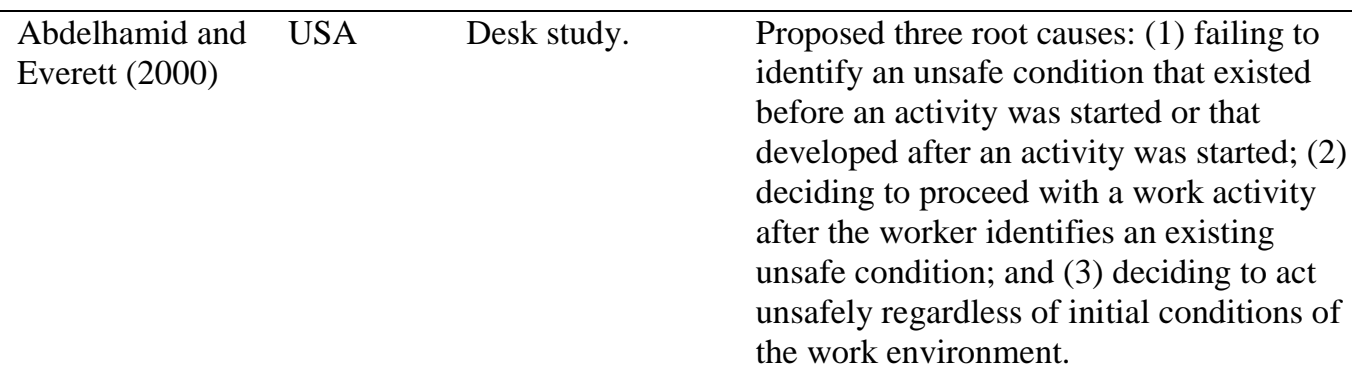

\begin{tabular}{|c|c|c|c|c|}
\hline $\begin{array}{l}\text { Egawa and } \\
\text { Nakamura } \\
(2000)\end{array}$ & Japan & $\begin{array}{l}\text { Examined } \\
\text { accident reports. }\end{array}$ & $\begin{array}{l}\text { Identified communication errors between } \\
\text { workers to be responsible for a large } \\
\text { number of accidents. }\end{array}$ & $\begin{array}{l}\text { Proximate causes } \\
\text { which do not } \\
\text { extend upstream of } \\
\text { project } \\
\text { procurement. }\end{array}$ \\
\hline
\end{tabular}

\begin{tabular}{lll}
\hline Lubega et al. & Uganda & A case study \\
& involving \\
& & interviews, and a \\
& questionnaire \\
& survey.
\end{tabular}

Reported causes of accidents include: lack of awareness of safety regulations; lack of enforcement of safety regulations; poor regard for safety by people involved in construction projects; engaging incompetent personnel; non-vibrant professionalism; mechanical failure of construction machinery/equipment; physical and emotional stress; and chemical impairment.

\begin{tabular}{lll}
\hline $\begin{array}{l}\text { Suraji } \text { et al. } \\
\text { (2001) }\end{array}$ & UK & Partial validation \\
& of Constraint \\
& Response model \\
& by analysis of \\
& 500 accidents.
\end{tabular}

$\begin{array}{ll}\text { Causes of accidents are: inappropriate } & \text { Proximate causes } \\ \text { construction planning (e.g. inadequate } & \text { which do not } \\ \text { method statement); inappropriate } & \text { extend upstream of } \\ \text { construction control (e.g. inadequate } & \text { project } \\ \text { supervision of operative work); } & \text { procurement. }\end{array}$

inappropriate site condition (e.g. unsuitable weather or climatic conditions); and inappropriate operative action (e.g. improper or inadequate use of PPE).

Toole (2002) USA $\quad$ Desk study.
Proposed that root causes of accidents are: lack of proper training; deficient enforcement of safety by supervisors; safety equipment not provided; unsafe methods or sequencing; unsafe site conditions; not using provided safety equipment; poor attitude towards safety; and isolated, sudden deviation from prescribed behaviour.

Proximate causes
which do not
extend upstream of
project
procurement.
procurement.

Proximate causes as well as underlying causes which extend upstream of project procurement.

Reported that root causes of accidents are: Proximate causes




\section{Appendix 1. Construction accident causation studies}

\begin{tabular}{|c|c|c|c|c|}
\hline Author & $\begin{array}{l}\text { Location } \\
\text { of study }\end{array}$ & Method of study & Causes of accident /findings & $\begin{array}{l}\text { Category of } \\
\text { causal factors }\end{array}$ \\
\hline Abraham (2004) & & $\begin{array}{l}\text { fatal trenching } \\
\text { accidents. }\end{array}$ & $\begin{array}{l}\text { lack of proper training; deficient } \\
\text { enforcement of safety by supervisors; } \\
\text { safety equipment not provided; unsafe } \\
\text { methods or sequencing; unsafe site } \\
\text { conditions; not using provided safety } \\
\text { equipment; poor attitude towards safety; } \\
\text { and isolated, sudden deviation from } \\
\text { prescribed behaviour. }\end{array}$ & $\begin{array}{l}\text { which do not } \\
\text { extend upstream of } \\
\text { project } \\
\text { procurement. }\end{array}$ \\
\hline Behm (2005) & USA & $\begin{array}{l}\text { Investigated the } \\
\text { link between } 230 \\
\text { construction fatal } \\
\text { accidents and the } \\
\text { design for safety } \\
\text { concept. }\end{array}$ & $\begin{array}{l}\text { Found that } 42 \% \text { of the fatal accidents are } \\
\text { associated with design factors. }\end{array}$ & $\begin{array}{l}\text { Underlying causes } \\
\text { which extend } \\
\text { upstream of } \\
\text { project } \\
\text { procurement. }\end{array}$ \\
\hline $\begin{array}{l}\text { Hinze et al. } \\
(2005)\end{array}$ & USA & $\begin{array}{l}\text { Examined } 743 \\
\text { 'struck by' } \\
\text { accident cases. }\end{array}$ & $\begin{array}{l}\text { Causes of accidents include misjudgement } \\
\text { of hazardous situation; malfunction of } \\
\text { procedure for securing operation or } \\
\text { warning of hazardous situation; and } \\
\text { inappropriate procedure for handling } \\
\text { materials for task. }\end{array}$ & $\begin{array}{l}\text { Proximate causes } \\
\text { which do not } \\
\text { extend upstream of } \\
\text { project } \\
\text { procurement. }\end{array}$ \\
\hline Chi et al. (2005) & Taiwan & $\begin{array}{l}\text { Examined } 621 \\
\text { occupational fatal } \\
\text { accidents. }\end{array}$ & $\begin{array}{l}\text { Causes of accidents include: lack of } \\
\text { complying scaffold/platform; unguarded } \\
\text { openings; and lack of fixed barrier. }\end{array}$ & $\begin{array}{l}\text { Proximate causes } \\
\text { which do not } \\
\text { extend upstream of } \\
\text { project } \\
\text { procurement. }\end{array}$ \\
\hline $\begin{array}{l}\text { Haslam et al. } \\
(2005)\end{array}$ & UK & $\begin{array}{l}\text { Focus group } \\
\text { interviews and } \\
\text { analysis of } 100 \\
\text { accidents. }\end{array}$ & $\begin{array}{l}\text { Causal factors are: immediate accident } \\
\text { circumstance (e.g. suitability and usability } \\
\text { of materials and equipment); shaping } \\
\text { factors (e.g. site conditions, site } \\
\text { layout/space, and work scheduling ); and } \\
\text { originating influences (e.g. permanent } \\
\text { works design and project management ) }\end{array}$ & $\begin{array}{l}\text { Proximate causes } \\
\text { as well as } \\
\text { underlying causes } \\
\text { which extend } \\
\text { upstream of } \\
\text { project } \\
\text { procurement. }\end{array}$ \\
\hline $\begin{array}{l}\text { Bomel Limited } \\
\text { et al. (2006) }\end{array}$ & UK & $\begin{array}{l}\text { Examined } 27 \text { and } \\
63 \text { fatal } \\
\text { accidents. }\end{array}$ & $\begin{array}{l}\text { Causal factors are: direct level factors; } \\
\text { organisational level factors; and policy } \\
\text { level factors. }\end{array}$ & $\begin{array}{l}\text { Proximate causes } \\
\text { which do not } \\
\text { extend upstream of } \\
\text { project } \\
\text { procurement. }\end{array}$ \\
\hline $\begin{array}{l}\text { Choudhry and } \\
\text { Fang (2008) }\end{array}$ & $\begin{array}{l}\text { Hong } \\
\text { Kong }\end{array}$ & $\begin{array}{l}\text { Interviews with } \\
\text { seven operatives, } \\
\text { two site } \\
\text { engineers, two } \\
\text { safety managers } \\
\text { and one project } \\
\text { manager. }\end{array}$ & $\begin{array}{l}\text { Accident causes are inadequate } \\
\text { supervision, inadequate training, } \\
\text { inadequate planning, employee error, and } \\
\text { accident beyond ones control. }\end{array}$ & $\begin{array}{l}\text { Proximate causes } \\
\text { which do not } \\
\text { extend upstream of } \\
\text { project } \\
\text { procurement. }\end{array}$ \\
\hline $\begin{array}{l}\text { Hamid et al. } \\
(2008)\end{array}$ & Malaysia & $\begin{array}{l}\text { Analysis of } 128 \\
\text { accident cases } \\
\text { and a } \\
\text { questionnaire } \\
\text { survey. }\end{array}$ & $\begin{array}{l}\text { Causes of accidents are unsafe equipment, } \\
\text { job site conditions, unique nature of } \\
\text { industry (e.g. work at height, transient } \\
\text { workforce, high energy required, } \\
\text { limitation of working area), unsafe } \\
\text { method, human element (e.g. negligence), } \\
\text { and management (e.g. poor inspection). }\end{array}$ & $\begin{array}{l}\text { Proximate causes } \\
\text { which do not } \\
\text { extend upstream of } \\
\text { project } \\
\text { procurement. }\end{array}$ \\
\hline Ling et al. & Singapore & Examined 40 & Causes of accidents are rushing to & Proximate causes \\
\hline
\end{tabular}




\section{Appendix 1. Construction accident causation studies}

\begin{tabular}{|c|c|c|c|c|}
\hline Author & $\begin{array}{c}\text { Location } \\
\text { of study }\end{array}$ & Method of study & Causes of accident /findings & $\begin{array}{c}\text { Category of } \\
\text { causal factors }\end{array}$ \\
\hline (2009) & & $\begin{array}{l}\text { fatal construction } \\
\text { accidents. }\end{array}$ & $\begin{array}{l}\text { complete work, working without using } \\
\text { personal protective equipment, lack of } \\
\text { safety awareness, personal negligence, } \\
\text { carelessness, and lack of supervision. }\end{array}$ & $\begin{array}{l}\text { which do not } \\
\text { extend upstream of } \\
\text { project } \\
\text { procurement. }\end{array}$ \\
\hline $\begin{array}{l}\text { Brace et al. } \\
(2009)\end{array}$ & UK & $\begin{array}{l}\text { Interviews with } \\
\text { experts and } \\
\text { stakeholders. }\end{array}$ & $\begin{array}{l}\text { Causal factors are: macro factors (e.g. } \\
\text { immature corporate systems; inappropriate } \\
\text { enforcement; and lack of leadership from } \\
\text { government as a key client); messo factors } \\
\text { (e.g. immature project systems and } \\
\text { processes; and inappropriate procurement } \\
\text { and supply chain arrangements); micro } \\
\text { factors (e.g. lack of individual competency } \\
\text { and understanding of workers and } \\
\text { supervisors; and poor behaviour). }\end{array}$ & $\begin{array}{l}\text { Proximate causes } \\
\text { as well as } \\
\text { underlying causes } \\
\text { which extend } \\
\text { upstream of } \\
\text { project } \\
\text { procurement. }\end{array}$ \\
\hline $\begin{array}{l}\text { Cooke and } \\
\text { Lingard (2011) }\end{array}$ & Australia & $\begin{array}{l}\text { Analysis } 258 \\
\text { construction } \\
\text { work-related } \\
\text { deaths using the } \\
\text { ConCA model by } \\
\text { Haslam } \text { et al. } \\
(2005) \text {. }\end{array}$ & $\begin{array}{l}\text { Of the } 258 \text { cases, no clear causes were } \\
\text { identified for } 66 \text { cases, and immediate } \\
\text { causes (e.g. local hazards, layout, } \\
\text { equipment usability, material usability) } \\
\text { were identified in the remaining } 192 \text { cases. } \\
\text { Of the } 192 \text { cases for which immediate } \\
\text { causes were identified, inter-mediate } \\
\text { causes/shaping factors (e.g. supervision, } \\
\text { site constraints, work scheduling, and } \\
\text { housekeeping) were identified in } 121 \text { cases } \\
\text { out of which originating influences (e.g. } \\
\text { client requirement, permanent works } \\
\text { design and project management) were also } \\
\text { identified in } 87 \text { cases. }\end{array}$ & $\begin{array}{l}\text { Proximate causes } \\
\text { as well as } \\
\text { underlying causes } \\
\text { which extend } \\
\text { upstream of } \\
\text { project } \\
\text { procurement. }\end{array}$ \\
\hline $\begin{array}{l}\text { Behm and } \\
\text { Schneller (2012) }\end{array}$ & USA & $\begin{array}{l}\text { Analysis } 27 \\
\text { construction } \\
\text { accidents using } \\
\text { the ConCA } \\
\text { model by Haslam } \\
\text { et al. }(2005) \text {. }\end{array}$ & $\begin{array}{l}\text { Identified causes of accident s are: } 81 \\
\text { immediate causes (e.g. suitability and } \\
\text { usability of equipment); } 47 \text { shaping factors } \\
\text { (e.g. supervision, and site constraint); and } \\
51 \text { originating influences (e.g. permanent } \\
\text { works design and project management). }\end{array}$ & $\begin{array}{l}\text { Proximate causes } \\
\text { as well as } \\
\text { underlying causes } \\
\text { which extend } \\
\text { upstream of } \\
\text { project } \\
\text { procurement. }\end{array}$ \\
\hline $\begin{array}{l}\text { Aulin and Agren } \\
\text { (2012) }\end{array}$ & Sweden & $\begin{array}{l}\text { Analysis of fatal } \\
\text { and non-fatal } \\
\text { accidents. }\end{array}$ & $\begin{array}{l}\text { Causes of accidents include: loss of } \\
\text { control; fall of person; collapse, fall, and } \\
\text { breaking of material; physical } \\
\text { strain/pressure; electrical problems, fire, } \\
\text { and explosion; leak, outflow, and } \\
\text { overflow; and shock, fright, violence, } \\
\text { aggression and threat. }\end{array}$ & $\begin{array}{l}\text { Proximate causes } \\
\text { which do not } \\
\text { extend upstream of } \\
\text { project } \\
\text { procurement. }\end{array}$ \\
\hline
\end{tabular}

